\title{
Acute retinal necrosis syndrome
}

\author{
D S Gartry, D J Spalton, A Tilzey, P G Hykin
}

\begin{abstract}
Acute retinal necrosis (ARN) is a rare syndrome with characteristic fundal appearances which can have devastating effects on vision. We present six cases (nine eyes) seen in the Medical Eye Unit of St Thomas's Hospital over the past six years and discuss the clinical features, aetiology, and management. Our findings support the present consensus that the condition is caused by varicella zoster virus (VZV) or herpes simplex virus (HSV). One of our patients, who was atypical in having common variable hypogammaglobulinaemia, had suffered a widespread zosteriform rash immediately prior to the onset of ARN, while another had suffered a herpes simplex uveomeningoencephalitis. All cases had characteristic confluent peripheral retinal necrosis, and three of the nine eyes developed retinal detachment. Retinal arteritis was a prominent and helpful diagnostic feature in one case. From combining all reports to date of this rare condition it is possible to conclude that $A R N$ is unilateral in $65 \%$ of cases.
\end{abstract}

The acute retinal necrosis syndrome (ARN), first described in Japan in $1971,{ }^{1}$ is characterised by panuveitis, vitritis, vaso-occlusive retinal arteritis, and necrotising retinitis. It is rapidly progressive and often has a devastating effect on vision due to retinal arteritis, retinal necrosis, and rhegmatogenous and traction retinal detachment. According to Culbertson $e a^{2{ }^{3}}$ the disease is bilateral in $36 \%$ of cases. The sexes are affected equally, and patients are usually well, with no significant past medical or ocular history. In $50 \%$ to $75 \%$ of patients the retina becomes detached within three months of the onset of symptoms. ${ }^{245}$ In $76 \%$ the final visual acuity is less than

St Thomas's Hospital, London SE1 7EH Department of Ophthalmology DS Gartry D J Spalton PG Hykin

Department of Virology A Tilzey

Correspondence to: Mr D S Gartry, FRCS Medical Eye Unit, $S$ t Thomas's Hospital, London SEl 7EH.

Accepted for publication 13 November 1990

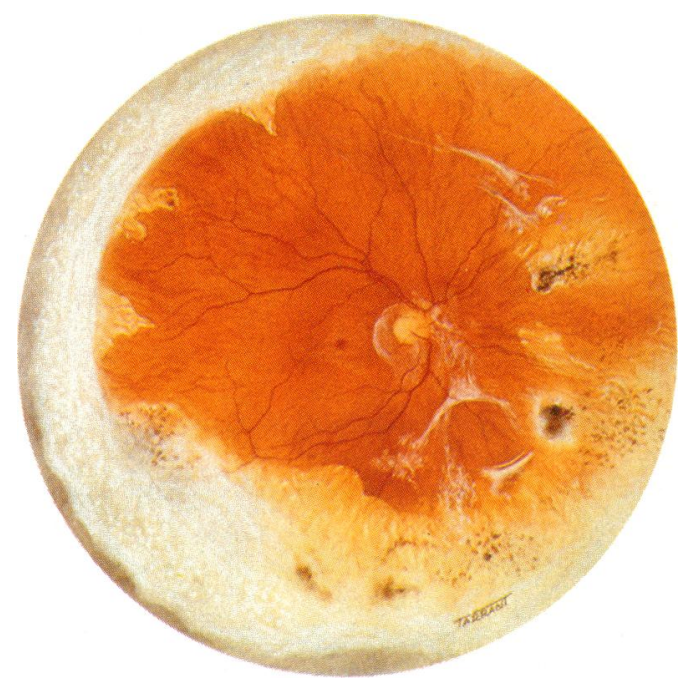

Figure 1 Retinal drawing of the right eye of case 1 showing peripheral retinal necrosis and scarring with early pigmentation.
$6 / 60$, and visual prognosis may also be poor owing to macular oedema and optic nerve damage secondary to vascular insufficiency.

In most cases little or no improvement has been achieved by medical or surgical treatment. As the herpes group of viruses has been implicated, ${ }^{2346-21}$ antiviral agents such as acyclovir and gancyclovir have been used in the acute phase, ${ }^{22}$ with limited success. The retinitis is reduced by these agents but the vitritis is unaffected, and there is still progression to retinal detachment. ${ }^{3}$

A recent report has, however, documented a milder form of the condition, and the authors ${ }^{23}$ suggest that some cases may be subclinical, forming one end of a spectrum of disease. Case 6 below belongs to this category.

\section{Case reports}

CASE I

Mrs M, a 65-year-old patient with susceptibility to upper and lower respiratory tract infections, underwent a lobectomy in 1985 for removal of a lung abscess and prior to surgery was diagnosed as having common variable hypogammaglobulinaemia. No specific treatment was given. In July 1987 she presented with chickenpox, which was treated with antibiotics (pivampicillin $500 \mathrm{mg}$ once a day) and systemic steroids (prednisolone $5 \mathrm{mg}$ once a day orally). Two weeks later she notice blurring of vision and haloes round lights. Visual acuities were RE 6/18 and LE 6/12. Immunoglobulins were administered intravenously three times a week. Three months later her vision had fallen to $6 / 60$ and $6 / 18$, and a diagnosis of viral retinitis was made. Treatment with topical steroids (dexamethasone eye drops $0 \cdot 1 \%$ four times a day) was instituted, but her vision continued to deteriorate until April 1988, when intravenous acyclovir was begun ( $450 \mathrm{mg}$ intravenously three times a day for two weeks), and a series of orbital floor steroid injections (beclomethasone $4 \mathrm{mg}$ ) were given.

On transfer to St Thomas's Hospital the visual acuities were 6/60 and counting fingers. Pupils were irregular, though responses were normal. No Ishihara plates were correctly identified, and examination of the visual fields showed reduced sensitivity, with patchy areas of loss indicative of retinal dysfunction. There were a few cells in both anterior chambers, intraocular pressures were normal, and there was considerable vitreous debris and syneresis. In the right eye there was a dense posterior vitreous infiltrate, with a limited posterior vitreous detachment. In the periphery large confluent areas of white retina extended almost $360^{\circ}$, with patchy pigmentation extending from the peripheral necrosis to the pre- and postequatorial regions (Fig 1). In the left eye there was a subtotal retinal 


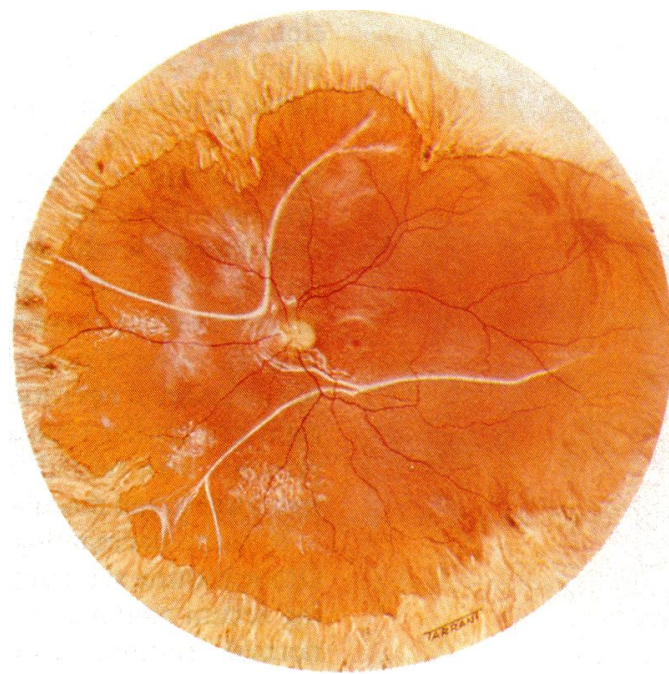

Figure 2 Retinal drawing of the left eye of a case 1 showing a subtotal retinal detachment with typical late phase peripheral retinal pigmentary changes characteristic of $A R N$.

detachment with no breaks apparent and several areas of subretinal fibrosis (Fig 2).

The blood picture was consistent with chronic disease with a low serum iron, though the haemoglobin was only slightly reduced. There was a relative lymphocytopaenia of $0.61 \times 10^{6} / 1$ (normal range 1.5-3.5), and the total protein was $49 \mathrm{~g} / 1$ (albumin $38 \mathrm{~g} / \mathrm{l}$, globulin $11 \mathrm{~g} / \mathrm{l}$; normal range $20-35)$. The hypogammaglobulinaemia was confirmed (in spite of the intravenous immunoglobulin treatment), with IgG $1.8 \mathrm{~g} / 1$ (normal range 5.3-16.5), IgA less than $0 \cdot 1 \mathrm{~g} / \mathrm{l}$ $(0 \cdot 8-4 \cdot 0)$, and $\operatorname{IgM}$ less than $0 \cdot 1 \mathrm{~g} / 1(0 \cdot 5-2 \cdot 0)$. No antibodies to varicella zoster virus (VZV) or herpes simplex virus (HSV) were detected by complement fixation test (CFT) in serum or cerebrospinal fluid (CSF) taken in April 1988 following transfer to St Thomas's Hospital. Both were also negative for antibodies to toxoplasma by latex agglutination. VZV IgG was detected in serum but not CSF by enzyme-linked immunosorbent assay (ELISA), but VZV IgM was not detected in either specimen. Serological tests were unlikely to be helpful in this patient, since she had common variable hypogammaglobulinaemia and had received regular infusions of immunoglobulins. Furthermore, the samples for the tests were taken nine months after the onset of varicella, and at this stage one is unlikely to find evidence of a recent or current viral infection unless viral antigen persists in sufficient quantity.

The clinical appearances were consistent with late phase ARN. As treatment with acyclovir and local and systemic steroids had already been instituted with limited effect, no further medical treatment was undertaken. The common variable hypogammaglobulinaemia was treated with intravenous immunoglobulins $(0.2 \mathrm{~g} / \mathrm{kg})$ to establish a serum IgG of $3 \mathrm{~g} / \mathrm{l}$.

In May 1988 left retinal detachment surgery was undertaken with cryopexy to necrotic retina, air injection, encirclement, and 30\% SF6 gas/air exchange. No retinal breaks were found at surgery. A vitreous aspirate was put into tissue culture, but no virus was isolated. Over the course of two weeks subretinal fluid was gradually reabsorbed, and, although subretinal

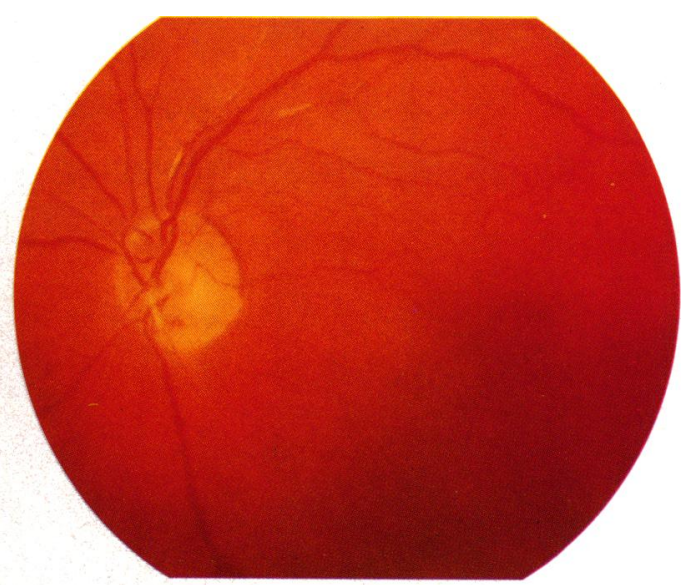

Figure 3A Colour photograph of case 2 taken at time of presentation showing an arteritis of the superior and inferior branch retinal arteries of the left eye.

fibrosis was still evident, the retina flattened. One year later vision in the right eye was $6 / 24$, and the left remained stable with counting fingers and good projection, with the retina attached.

\section{CASE 2}

Mrs V, a 61-year-old housewife, presented in February 1987 with a one-month history of blurred vision and floaters in the right eye. A diagnosis of mild acute anterior uveitis was made, which was treated topically. Unaided vision was RE 6/9 and LE 6/12. A few days later inflammatory cells were noted in the vitreous of the right eye and the diagnosis was revised to posterior uveitis. Shortly after this the vision in the right eye fell dramatically to counting fingers. She was otherwise entirely well, with no recent or previous medical history of note.

Examination of the right eye showed occlusion of peripheral and central retinal arterioles and a subtotal rhegmatogenous retinal detachment, with several small breaks at the junction between normal and necrotic retina. Peripheral arteritis was noted in the left eye as well as peripheral retinal necrosis (Figs 3A, B). A diagnosis of ARN was made based on the clinical appearances.

Routine haematological indices were entirely normal. A serum sample taken at the time of

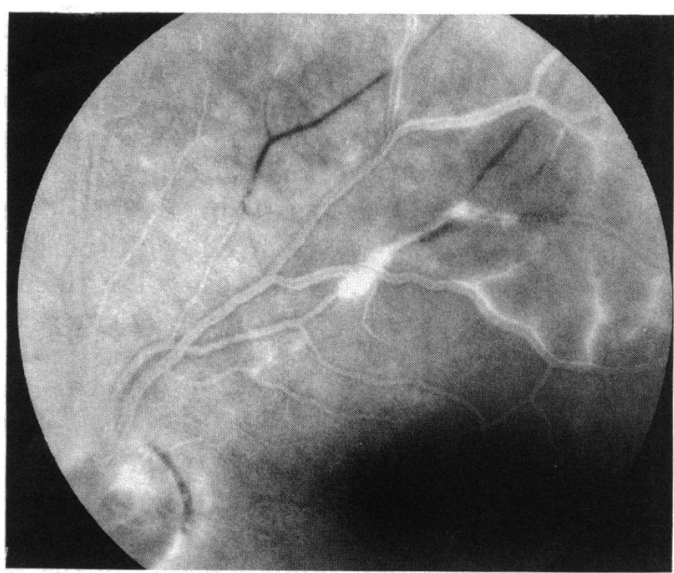

Figure 3B Fluorescein angiogram of the left eye of case 2 at presentation showing failure of the supero-temporal branch retinal artery with leakage from the vessel and secondary venous changes as well as optic disc hypo-fluorescence. 


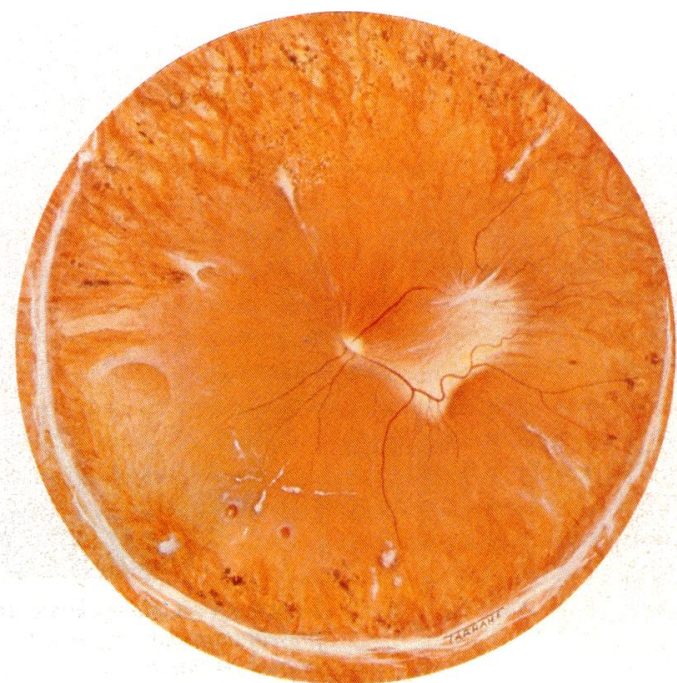

Figure 4 Retinal drawing of the left eye of case 3 showing a subtotal retinal detachment with periretinal fibrosis and retinal breaks in the inferonasal quadrant at junctions of normal and necrotic retina.

presentation had no detectable antibody to HSV or cytomegalovirus (CMV) but a titre of 20 to VZV by CFT. Two conventional retinal detachment procedures were undertaken before the right retina was successfully reattached. Vision improved to $6 / 18$. The serum sample and a sample of subretinal fluid obtained at surgery were examined by ELISA for IgG antibodies to VZV and HSV and IgM antibodies to VZV. VZV IgG was twice as high in the subretinal fluid as in the serum. Furthermore, although VZV IgM was not detected in serum, it was detected at a high level in the subretinal fluid. These results were consistent with local antibody production, but one cannot be certain that they were not due to non-specific factors, since there are insufficient data on the serology of intraocular fluids. Unfortunately, there was insufficient subretinal fluid for tissue culture. The visual acuity in both eyes has remained stable (right $6 / 18$ and left 6/12).

\section{CASE 3}

$\mathrm{Mr} \mathrm{K}$, a 40-year-old boat skipper, presented in November 1985 with decreased vision $(6 / 60)$ in his left eye. On examination he was found to have a granulomatous panuveitis. His right eye was normal, and after treatment with systemic steroids (prednisolone enteric coated $20 \mathrm{mg}$ once a day) the left eye improved to 6/24. A course of pulsed methylprednisolone (500 $\mathrm{mg}$ intravenously three times a day) improved visual acuity to $6 / 9$, but one month later the panuveitis recurred, with signs of early involvement of the right eye. Treatment with systemic steroids (prednisolone enteric coated $20 \mathrm{mg}$ once a day) was again instituted, and visual acuities stabilised at $6 / 5$ and $6 / 18$. He had previously been entirely well, and routine investigations to determine the cause of the uveitis gave normal results. In January 1986 he developed a shallow retinal detachment in the left eye and increased inflammation in the right despite further treatment with pulsed methylprednisolone.

On transfer to St Thomas's Hospital the vision in the right eye was $6 / 12$ and in the left percep- tion of light. There was a left relative afferent pupil defect. Colour vision (Ishihara plates) and visual fields in the right eye were normal. There were a few cells in the anterior chambers and in both vitreous cavities, with considerable syneresis in the left. There was a subtotal retinal detachment in the left eye with massive periretinal fibrosis and extensive peripheral chorioretinal scarring characteristic of late phase ARN (Fig 4). Several retinal breaks were detected at the junction of necrotic and normal retina. In the right eye similar typical late phase changes were present, with retinal folds and scarring superotemporal to the macula.

Routine haematological indices were normal. Other routine screening tests for uveitis, including serum angiotensin converting enzyme, gave normal results. Two serum samples were obtained in May and June 1986, with a left aqueous tap being performed at the same time as the second serum sample was taken. Antibodies to HSV were detected by CFT in both sera at a titre of 40 and in the aqueous at a titre of 8 . Antibodies to VZV were also detected by CFT in both sera at a titre of 20 but at a titre of 32 in aqueous. Although this could be consistent with local production, leakage and concentration of antibody secondary to the vasculitic process found in this condition cannot be excluded. VZV and HSV IgG were detected in both sera and aqueous by ELISA, but VZV IgM was not detected in any of these samples. Aqueous was put into tissue culture but no virus was isolated.

Oral systemic steroids were continued in reducing doses. The appearances were consistent with late phase $A R N$, and it was thought that retinal detachment surgery for the left eye would not give any further visual improvement. Vision has remained unchanged since the patient's discharge in June 1986.

\section{CASE 4}

Mr L, aged 68, presented to the casualty department of St Thomas's Hospital in June 1984 with sudden onset of dizziness, nausea and vomiting, anorexia, difficulty in walking, and inability to concentrate. He was found to be pyrexial $\left(39^{\circ} \mathrm{C}\right)$ and stuporose, with a blood pressure of $180 / 110$ $\mathrm{mmHg}$ and a pulse of 100 beats per minute. There was some limitation of left gaze and evidence of left-sided sensory inattention. Plantar reflexes were upgoing.

On admission to hospital a lumbar puncture showed a lymphocyte pleocytosis $\left(75 \times 10^{6} / 1\right.$ white cells, $99 \%$ lymphocytes). A CT scan was normal. A presumptive diagnosis of herpes meningoencephalitis was made and treatment started with intravenous acyclovir (400 $\mathrm{mg}$ three times a day) and continued for three weeks. Antituberculosis triple therapy was also begun, as it was impossible to exclude this alternative diagnosis at the time of presentation. He had been entirely well beforehand. Apart from a mild leucocytosis the blood indices were within normal limits. Paired sera taken during the initial admission eight days apart showed a significant rise in antibodies by CFT to HSV (from $<10-80$ ). A significant rise in antibodies to HSV was subsequently shown in two CSF 
samples taken at presentation in June and in August (from <4-32). Seroconversion was also demonstrated in the paired CSF samples by ELISA, and albumin/globulin ratios confirmed intrathecal synthesis of antibodies. These findings were consistent with the diagnosis of HSV meningoencephalitis. His condition improved slowly.

One month later, while still an inpatient, he developed a painful, red right eye with a panuveitis and reduced acuity (6/24). The left eye was entirely normal. Examination of the right fundus showed areas of peripheral confluent white retinitis, and a clinical diagnosis of HSV uveomeningoencephalitis was made. Treatment with topical acyclovir (3\% five times a day), dexamethasone $(0.1 \%$ four times a day) and atropine $(1 \%$ twice a day) was added to the regimen.

He was discharged on oral acyclovir $(200 \mathrm{mg}$ five times a day) combined with the topical regimen. Six weeks later he was readmitted complaining of decreased vision in the right eye, in which vision was found to have deteriorated to counting fingers. Further examination showed an extensive $360^{\circ}$ peripheral retinal necrosis and a dense vitreous infiltrate.

Oral prednisolone $60 \mathrm{mg}$ once a day was added, and the vision in the right eye improved slightly to $4 / 60$. Once the eye was stable, the steroids were tailed off. In May 1987 a right cataract extraction was performed, with little improvement in acuity owing to macular oedema.

\section{CASE 5}

Mr G, aged 64, presented in September 1987 with a one-week history of a painful left eye and marked deterioration of vision. He had lost all useful vision in his right eye owing to uveitis in 1972. There had been no other relevant history of illness, and on admission he was entirely well. His right eye was phthisical and vision in the left was reduced to counting fingers. There was evidence of a left panuveitis with dense vitreous infiltrate and characteristic lesions of active ARN affecting the peripheral retina.

All haematological indices were within normal limits. Two serum samples were obtained one and two weeks after the onset of symptoms, and a CSF sample was also taken at presentation. There was no rise in antibodies by CFT to HSV, $\mathrm{VZV}$, or CMV, and toxoplasma antibodies were not detected in either sample by latex agglutination. No antibodies were detected in the CSF by CFT. The first serum sample and the CSF were tested for VZV IgG and IgM by ELISA. VZV IgG was positive in the serum but not the CSF, and the test for VZV IgM was negative in both samples. These serological findings are consistent with immunity to varicella, and there was no evidence in support of a specific viral aetiology. Treatment was begun with acyclovir $(350 \mathrm{mg}$ intravenously three times a day) and systemic steroids (prednisolone enteric coated $50 \mathrm{mg}$ once a day). After two weeks the retinal appearance improved, with reduction in the activity throughout the eye and improvement in vision to $3 / 60$. Oral acyclovir $800 \mathrm{mg}$ four times a day was then substituted for a further two weeks and the steroids gradually tailed off. The optic disc was noted to be pale, the retinal vessels attenuated, and the peripheral retina necrotic, with areas of pigmentary scarring. He was discharged three weeks after admission and since then has had no further visual improvement.

CASE 6

Mrs D, aged 42, was referred for assessment after she had suffered a rapid deterioration of vision in her left eye in May 1988. The only previous ocular problem had been the onset of floaters in the left eye in December 1987, and there had been no pain or redness in either eye. Her general health was excellent.

On examination the visual acuities were right eye $6 / 5$ and left eye $6 / 60$. The anterior segments were normal. The left eye had a small vitreous haemorrhage and peripheral chorioretinal pigmentary scarring extending from 3 o'clock to 9 o'clock from the ora to the equator. The right eye was entirely normal.

The sudden deterioration in vision was due to the vitreous haemorrhage, and it seemed likely that the appearance of floaters five months earlier represented ARN which had resolved spontaneously, leaving the typical late phase appearances. Blood indices and results of virology studies proved to be normal. A serum sample taken in May 1988 provided no evidence to support any underlying causative agent, and since the clinical findings indicated no disease activity no active treatment was instituted. After two weeks the vitreous haemorrhage resolved, and subsequently the visual acuity improved to $6 / 6$.

\section{Discussion}

Acute retinal necrosis (ARN; Kirasawa-type uveitis $^{24}$ ) was first described by Urayama et al in 1971. ${ }^{1}$ In 1977 Willerson, et al ${ }^{25}$ reported on two patients with bilateral necrotising vaso-occlusive retinitis of unknown origin. In 1978 Young and Bird described four cases of bilateral ARN. Since all previous cases had also been bilateral, the acronym BARN was adopted. ${ }^{26} \mathrm{~A}$ viral aetiology was suspected but not proved. In 1980 Price and Schlaegel emphasised the severity of ARN by presenting the case of a 20-year-old girl who lost all useful vision within a few weeks. ${ }^{27}$ Hayreh et al presented nine cases in 1980 of which only four were bilateral, and it was realised that the condition did not always affect both eyes. ${ }^{28}$ Since these early descriptions about 60 cases have been reported in the world literature, and as $65 \%$ have been unilateral ARN has become the recognised description.

The stages of the disease process have been defined as acute and late. The syndrome has an insidious onset with a mild anterior uveitis and slight reduction in visual acuity. There may be ocular pain and increased intraocular pressure. A panuveitis follows. Rapid progression then ensues over a matter of days or weeks, during which time large areas of peripheral retina become white and necrotic, eventually coalescing to produce confluent peripheral retinal necrosis. A vaso-occlusive retinal vasculitis can 
be observed during this phase, which particularly affects the retinal arterioles (Figs 3A, B). Vitreous turbidity is increased and retinal traction may begin at this stage. ${ }^{4} \mathrm{~A}$ swollen optic nerve head and arcuate neuroretinitis have been noted in the acute phase, ${ }^{29}$ but most reports describe a relative sparing of the posterior pole. The second eye, if affected, usually becomes involved within weeks to months.

With evolution to the late phase the cloudy white, necrotic peripheral retinal areas regress, leaving sharply demarcated zones with mild pigmentary scarring (Fig 2) and increased vitreous debris. ${ }^{4}$ Visual acuity may rapidly worsen at this stage because of occlusion of vessels supplying the optic nerve head and central retina. Fibrous organisation of the vitreous may lead to traction retinal detachment. Rhegmatogenous detachment also occurs, the breaks usually being located at junctions between necrotic and normal retina (Fig 4). Surgery is technically difficult, and even with a good anatomical result (as in case 1) the final visual outcome may be poor because of optic atrophy, macular pucker, and macular oedema. $^{3422}$

From 1982 onwards reports have implicated the herpes group of viruses in ARN. ${ }^{6-21}$ Culbertson et $a l^{2}$ examined an enucleated eye from a patient with ARN and confirmed histologically a retinal arteritis and eosinophilic intranuclear inclusions in the retinal cells consistent with herpes zoster retinitis. ${ }^{6}$ The sharp demarcation of affected retina was also confirmed histologically and is characteristic of cell to cell viral spread. Electron microscopy confirmed a herpes group virus, but specific serology was unhelpful. In 1986 Culbertson $e t a l^{3}$ examined two more enucleated eyes from patients with ARN. Immunocytopathologic techniques confirmed the presence of $\mathrm{VZV}$, which was also cultured from vitreous. Further confirmation was given by DNA restriction enzyme analysis. When these newer techniques were applied to material from the original case, VZV was detected. ${ }^{3}$

Numerous reports have supported the claim that ARN is caused by VZV. ${ }^{36-14}$ In 1986 Yeo

Table 1 Examination findings and retinal detachment descriptions in six cases of acute retinal necrosis

\begin{tabular}{|c|c|c|c|c|}
\hline \multirow[b]{2}{*}{ Case } & \multirow[b]{2}{*}{ Age } & \multirow[b]{2}{*}{ Sex } & \multicolumn{2}{|l|}{ Examination findings } \\
\hline & & & Right eye & Left eye \\
\hline 1 & 65 & $\mathbf{F}$ & $\begin{array}{l}\text { AC inflammation, vitreous infiltrate, } \\
\text { confluent peripheral necrosis and } \\
\text { pigmentation (Fig } 1 \text { ) }\end{array}$ & $\begin{array}{l}\text { AC inflammation, subtotal traction, } \\
\text { retinal detachment and peripheral } \\
\text { pigmentary changes (Fig 2) }\end{array}$ \\
\hline 2 & 61 & $\mathbf{F}$ & $\begin{array}{l}\text { AC inflammation, vitreous inflammation, } \\
\text { retinal arteritis and subtotal } \\
\text { rhegmatogenous detachment. Retinal } \\
\text { breaks at demarcation lines }\end{array}$ & $\begin{array}{l}\text { Peripheral retinal arteritis and } \\
\text { peripheral retinal necrosis (Figs } 3 \mathrm{~A}, \mathrm{~B} \text { ) }\end{array}$ \\
\hline 3 & 40 & $M$ & $\begin{array}{l}\text { Mild panuveitis with increased activity } \\
\text { later and peripheral areas of confluent } \\
\text { pigmentation and scarring }\end{array}$ & $\begin{array}{l}\text { Mild panuveitis leading to a marked } \\
\text { panuveitis and shallow subtotal RD } \\
\text { with numerous breaks and massive } \\
\text { periretinal fibrosis and peripheral } \\
\text { scarring (Fig 4) }\end{array}$ \\
\hline 4 & 68 & $M$ & $\begin{array}{l}\text { Dense vitreous infiltrate with extensive } \\
\text { peripheral retinal necrosis. }\end{array}$ & Normal \\
\hline 5 & 64 & $M$ & Phthisical (uveitis 1972 no details) & $\begin{array}{l}\text { Panuveitis and dense vitreous infiltrate } \\
\text { Typical acute retinal necrosis changes } \\
\text { with peripheral pigmentary changes } \\
\text { and optic atrophy }\end{array}$ \\
\hline 6 & 42 & $\mathbf{F}$ & Normal & $\begin{array}{l}\text { Confluent peripheral retinal scarring, } \\
\text { vitreous haemorrhage and debris from } \\
\text { recent posterior vitreous detachment }\end{array}$ \\
\hline
\end{tabular}

$\mathrm{AC}=$ anterior chamber. $\mathrm{RD}=$ retinal detachment . et $a l$ reported on two patients, one with the Ramsay-Hunt syndrome and the other with maxillary division shingles, both of whom developed ARN. Indirect immunofluorescence revealed VZV with evidence of recent varicella zoster infection in the serum. Jampol, ${ }^{8}$ Browning et $a l^{9}$ and Brown and Mendis ${ }^{10}$ described similar cases. Case 1 here provides further circumstantial evidence that VZV is a causative agent, since ARN developed only two weeks after chickenpox. So far as we are aware this is the first recorded instance of ARN developing in a patient with common variable hypogammaglobulinaemia.

ARN in immunocompromised patients is rare. Friberg and Jost ${ }^{13}$ reported on a patient who was immunosuppressed following renal transplantation and who developed ARN preceded by $\mathrm{T} 2, \mathrm{~T} 3$, and T4 shingles with raised antibody titres to VZV. Similarly Freeman et $\mathrm{l}^{14}$ reported two cases of ARN in immunocompromised patients and one patient with AIDS. These cases have, however, been the exception. Cases 2 and 3 also support a VZV aetiology, since increased IgG and $\operatorname{Ig} M$ to VZV was demonstrated in subretinal fluid (case 2) and high antibody titres to VZV in aqueous (case 3), both findings being suggestive of local antibody production.

Several other reports have implicated HSV as a causative agent. ${ }^{15-21}$ Peyman et al reported two cases responding to intravenous acyclovir. ${ }^{15}$ Viral cultures were negative, but vitreous aspirate stained positive for HSV with immunofluorescence techniques. Other cases of ARN have been described ${ }^{16}$ in which herpes simplexlike vesicles were simultaneously observed on the skin. Lewis et $a l^{17}$ have recently reported isolating HSV-1 virus from the vitreous of two patients with ARN. In one of these magnetic resonance imaging (MRI) suggested that virus had spread along both optic tracts from the lateral geniculate bodies. Interestingly, in earlier cases of presumed VZV ARN no similar spread could be detected, suggesting a possible distinction in activity between the two viruses. It would seem that, although HSV retinitis is similar to VZV ARN, the two are distinct entities. In 1976 Minckler $e t$ al $^{18}$ reported the case of a 44-year-old man who died three weeks after simultaneous onset of HSV encephalitis and retinitis. The details are very similar to case 4 with the exception of the outcome, though the retinal changes described were not conclusively those of ARN. There was a 16-fold rise in HSV antibody within two weeks and cultures of brain tissue yielded HSV type 1. Intranuclear inclusion bodies typical of those produced by the herpes group were found in brain, optic nerves, retina, and choroid. Similarly, Cogan et al ${ }^{19}$ in 1964 described herpes simplex retinitis in a neonate, and a further description of HSV retinitis is given by Cibis et al. $^{20}$

Table 1 summarises the cases of ARN presented here. The herpes group of viruses was implicated in four of the six cases (Table 2). In cases 1, 2, and 3 (bilateral involvement) VZV was implicated, while in case 4 there was circumstantial evidence implicating HSV. In cases 5 and 6 the diagnosis was made on the typical fundus changes. Systemically these patients were 
Table 2 Final outcome and supporting evidence pointing to a herpes group virus as the aetiological agent

\begin{tabular}{|c|c|c|c|c|}
\hline \multirow[b]{2}{*}{ Case } & \multicolumn{2}{|c|}{$\begin{array}{l}\text { Final visual } \\
\text { acuity }\end{array}$} & \multirow{2}{*}{$\begin{array}{l}\text { Follow-up } \\
\text { period }\end{array}$} & \multirow[b]{2}{*}{ Evidence for proposed aetiology } \\
\hline & Right & Left & & \\
\hline 1 & $6 / 24$ & CF & 1 year & $\begin{array}{l}\text { Varicella zoster rash two weeks prior to the onset of typical acute } \\
\text { retinal necrosis }\end{array}$ \\
\hline 2 & $6 / 18$ & $6 / 12$ & 1 year & $\begin{array}{l}\text { Systemically well. VZV IgM detected in subretinal fluid but not in } \\
\text { the serum and a relatively high VZV IgG titre in the subretinal fluid } \\
\text { compared with serum }\end{array}$ \\
\hline 3 & $6 / 12$ & PL & 2 years & $\begin{array}{l}\text { Systemically well. A higher VZV complement fixation titre in } \\
\text { aqueous than in serum (both samples taken at the same time) }\end{array}$ \\
\hline 4 & $4 / 60$ & $6 / 6$ & 1 year & $\begin{array}{l}\text { Serologically confirmed HSV uveo-meningoencephalitis followed } \\
\text { by ARN one month later }\end{array}$ \\
\hline 5 & NPL & $3 / 60$ & 18 months & $\begin{array}{l}\text { No systemic associations and no serological evidence in support of a } \\
\text { viral aetiology }\end{array}$ \\
\hline 6 & $6 / 5$ & $6 / 6$ & 1 month & No systemic association. Negative serology \\
\hline
\end{tabular}

$\mathrm{CF}=$ counting fingers. $(\mathrm{N}) \mathrm{PL}=($ no $)$ perception of light.

normal and there was no justification for taking intraocular specimens. Three of the six cases were unilateral (though it is not possible to be sure of the nature of the previous 'uveitis' in the right eye of case 5).

Table 2 summarises the visual outcome. It is noteworthy that the cases with bilateral involvement $(1,2$, and 3$)$ had a poorer prognosis because of retinal detachment. In case 2 , however, a relatively good result was achieved in the right eye following detachment surgery. Case 4 (right eye affected) did poorly because of macular oedema rather than retinal detachment, and case 5 (left eye) had a final visual acuity of 3/60 18 months later because of optic atrophy. Matsuo et al reported a mild case of $A R N,{ }^{23}$ and it would seem that from our experience over the past four years a spectrum of ARN exists from mild uniocular disease, as in case 6 , to severe blinding bilateral disease.

The rarity of the disease makes a definitive approach to its management difficult. The diagnosis is essentially clinical, being suggested by retinal arteritis (which is an uncommon feature in uveitis in contrast to phlebitis) and the pathognomonic peripheral confluent retinal infiltration. The diagnosis should be supported by evidence of systemic infection, though this will be negative in most cases, and the appropriate analysis of intraocular specimens where these can be obtained. In the early stages intravenous acyclovir limits the retinal necrosis, and steroids reduce the ocular inflammation, though to what extent these improve the natural history of the condition is still unknown, as some cases, for example, case 6 and that of Matsuo et al, ${ }^{23}$ had a relatively benign and self limited course. Antiplatelet drugs have been given to some patients with the object of limiting the occlusive vasculitis, but this is an unproved treatment.

Retinal detachment occurred in three eyes. The causes were rhegmatogenous in two and traction in the third. In contrast to the other series no large breaks or giant tears were found. Han $e t a l^{22}$ reported the effects of prophylactic laser photocoagulation to prevent detachment from retinal breaks at areas of demarcation between necrotic and normal retina in five patients. After 15 months of follow-up no retinal detachments had occurred. These patients were also treated concurrently with acyclovir, steroids, and antiplatelet agents, all of which may have influenced the outcome.

The possibility of ARN in any patient presenting with an anterior uveitis and particularly in those with a recent history of herpes simplex or zoster infections must always be considered. Thorough examination of the peripheral fundus should be carried out in all cases to look for the physical signs of ARN, so that early diagnosis may be achieved, followed by appropriate chemotherapy and monitoring.

We thank Mr M D Sanders for allowing us to report case 4.

1 Urayama A, Yamada N, Sasaki T, et al. Unilateral acute uveitis with retinal peri-arteritis and detachment. $\mathcal{F} p n \mathcal{F}$ Clin Ophthalmol 1971; 25: 607-19.

2 Culbertson WW, Blumenkranz MS, Haines H, Gass DM, Mitchell KB, Norton EWD. The acute retinal necrosis syndrome. Part 2. Histopathology and aetiology. Ophthalmology 1982; 89: 1317-25.

3 Culbertson WW, Blumenkranz MS, Pepose JS, Stewart JA, Curtin VT. Varicella zoster virus is a cause of acute retinal necrosis syndrome. Ophthalmology 1986; 93: 559-69.

4 Fisher JP, Lewis ML, Blumenkranz MS, et al. The acute retinal necrosis syndrome. Part 1 . Clinical manifestations. Ophthalmology 1982; 89: 1306-16.

5 Clarkson JG, Blumenkranz MS, Culbertson WW, et al. Retinal detachment following the acute retinal necrosis syndrome. Ophthalmology 1984; 91 : 1665-8.

6 Schwartz JN, Cashwell F, Hawkins HK, et al. Necrotising retinopathy with herpes zoster ophthalmicus. A light and E M study. Arch Pathol Lab Med 1976; 100: 386-91.

7 Yeo JH, Pepose JS, Stewart JA, Sternberg P, Liss RA. Acute retinal necrosis syndrome following herpes zoster dermatitis. Ophthalmology 1986; 93: 1418-22.

8 Jampol LM. Acute retinal necrosis. Am $\mathcal{F}$ Ophthalmol 1982; 93: $254-5$.

9 Browning DJ, Blumenkranz MS, Culbertson WW. Association of varicella zoster dermatitis with acute retinal necrosis. tion of varicella zoster dermatit
Ophthalmology 1987; 94: 602-6.

Ophthalmology 1987; 94: 602-6.
10 Brown RM, Mendis U. Retinal arteritis complicating herpes zoster ophthalmicus. Brf Ophthalmol 1973; 57: 344-6.

11 Soushi S, Ozawa H, Matsuhashi M, Shimazaki J, Saga U, Kurata T. Demonstration of varicella zoster viral antigens in the vitreous aspirates of patients with acute retinal necrosis syndrome. Ophthalmology 1988;95: 1394-8.

12 Imura N, Imura $\mathrm{R}, \mathrm{Oku} \mathrm{H}$, et al. Rise of antibody titre fo varicella zoster virus in the aqueous and vitreous in two cases with Kirasawa uveitis. $\mathcal{F p n ~} \mathcal{f}$ Clin Ophthalmol 1985; 39 . $101-6$.

13 Friberg TR, Jost BF. Acute retinal necrosis in an immunocompromised patient. Am $\mathcal{F}$ Ophthalmol 1984; 98: 515-7.

14 Freeman WR, Thomas EL, Rao NA, et al. Demonstration of herpes group virus in acute retinal necrosis syndrome. herpes group virus in acute retina

15 Peyman GA, Goldberg MF, Uninsky E, Tessler H, Pulido J Hendricks R. Vitrectomy and intravitreal drug therapy in acute retinal necrosis syndrome. Arch Ophthalmol 1984; 91 $1659-64$.

16 Ludwig IH, Zegarra H, Zakov ZN. The acute retinal necrosis syndrome; possible herpes simplex retinitis. Ophthalmology 1984; 91: 1659-64.

17 Lewis ML, Culbertson WW, Post JD, et al. Herpes simplex virus type 1 . A cause of the acute retinal necrosis syndrome. Ophthalmology 1989; 96: 875-8.

18 Minckler DS, McLean EB, Shaw CM, Hendrickson A Herpes hominis encephalitis and retinitis. Arch Ophthalmol 1976; 94: 89-95.

19 Cogan DG, Kuwabara T, Young GF, et al. Herpes simplex retinopathy in an infant. Arch Ophthalmol 1964; 72: 641-5.

20 Cibis GW, Flynn JT, Davis AB. Herpes simplex retinitis. Arch Ophthalmol 1978; 96: 299-302.

21 Sarkies N, Gregor Z, Forsey T, Darougar S. Antibodies to herpes simplex type 1 in intraocular fluids of patients with acute retinal necrosis. BrF Ophthalmol 1986; 70: 81-4.

22 Han DP, Lewis H, Williams GA, Mieler WF, Abrams GW Aaberg TM. Laser photocoagulation in the acute retinal necrosis syndrome. Arch Ophthalmol 1987; 105: 1051-4.

23 Matsuo T, Nakayama T, Koyama T, Koyama M, Matsuo N A proposed mild type of acute retinal necrosis syndrome. Am A Ophthalmol 1988; 105: 579-83.

24 Bando K, Kinoshita A, Mimmura Y. Six cases of so-called Kirasawa-type uveitis. $\mathcal{F} p n \mathcal{F}$ Clin Ophthalmol 1979; 33: 1515-21.

25 Willerson D, Aaberg TM, Reeser FH. Necrotising vasoocclusive retinitis. Am $\mathcal{F}$ Ophthalmol 1977; 84: 209-19.

26 Young NJA, Bird AC. Bilateral acute retinal necrosis. $B r f$ Ophthalmol 1978; 62: 581-90.

27 Price FW, Schlaegel TF. Bilateral acute retinal necrosis. Am $\mathcal{F}$ Ophthalmol 1980;89: 419-24.

28 Hayreh MMS, Krieger AE, Straatsma BR, et al. Acute retinal necrosis. Invest Ophthalmol Vis Sci 1980; 19 (suppl 48): ARVO abstracts.

29 Margolis T, Irvine AR, Hoyt WF, Hyman R. Acute retinal necrosis syndrome presenting with papillitis and arcuate neuroretinitis. Ophthalmology 1988; 95: 937-40. 